\title{
BAHAYA MERKURI PADA MASYARAKAT DIPERTAMBANGAN EMAS SKALA KECIL (PESK) LEBAKSITU
}

\section{Yuli Kristianingsih}

\author{
Program studi DIII-Analis Kesehatan Universitas MH Thamrin, Jakarta
}

\begin{abstract}
ABSTRAK
Penambangan emas Lebaksitu adalah Pertambangan Emas Skala Kecil (PESK). Sistem pengolahannya menggunakan merkuri yang berpotensi menimbulkan pencemaran lingkungan dan gangguan kesehatan bagi masyarakat. Merkuri memiliki sejumlah efek yaitu antara lain mengakibatkan terganggunya fungsi hati dan ginjal, mengganggu sistem enzim dan mekanisme sintetik, merusak janin pada wanita hamil sehingga menyebabkan cacat bawaan, kerusakan DNA dan kromosom, mengganggu saluran darah ke otak serta menyebabkan kerusakan otak (Darmono, 2001). Penelitian ini bertujuan untuk mengetahui kadar merkuri dalam darah pada masyarakat terpajang merkuri di desa Lebaksitu. Desain studi yang digunakan ini adalah cross sectional. Penelitian dilakukan pada bulan Mei 2017,terdapat 68 responden yang termasuk dalam sampel penelitian ini setelah dilakukan penentuan kriteria inklusi dan eksklusi. Data diperoleh dari hasil uji laboratorium sampel darah dan hasil wawancara responden. Hasil penelitian dapat dijelaskan 77,9\% responden memiliki merkuri darah lebih dari $10 \mu \mathrm{g} / \mathrm{l}$ dan variabel lama tinggal mempengaruhi kadar merkuri dalam darah masyarakat di Lebaksitu.
\end{abstract}

Kata Kunci : PESK, Merkuri

\section{PENDAHULUAN}

Pertambangan emas skala kecil atau pertambangan emas rakyat tersebar sebanyak 850 titik di Indonesia (Ratnasari, 2014). Pemilahan emas pada pertambangan tersebut dilakukan dengan menggunakan merkuri (Setiabudi, 2005; Ratnasari, 2014). Menurut United Nations Environment Programme (2012), pemakaian merkuri dari pertambangan emas rakyat diestimasi sekitar 1400 ton/tahun sehingga menjadi sektor permintaan terbesar secara global. Sektor ini menghasilkan 12-15\% dari emas dunia. Selain itu, pertambangan emas rakyat adalah mata pencaharian bagi jutaan orang dan sumber pencemaran merkuri yang utama(Sippl, 2015). Penggunaan merkuri pada pemilahan emas ini disebut dengan proses amalgamasi. 25-30\% merkuri yang ditambahkan dalam proses ini hilang ke lingkungan (Veiga et al., 2009).

Emisi merkuri dari tambang emas rakyat merupakan masalah lingkungan serius di negara-negara berkembang (Bose-O'Reilly, 2010). Penelitian di Indonesia banyak orang yang bekerja atau tinggal di area pertambangan emas sangat rentan terkena merkuri anorganik.Survei oleh Rianto tahun 2010 di Wonogiri diketahui rata-rata kandungan merkuri dalam darah pekerja 53,5 $\mu \mathrm{g} / 1$ (Rianto, 2010).Penelitian yang dilakukan Dewanti (2013) 97,56\% kadar merkuri dalam darah pada masyarakat sudah melebihi standar WHO (5$10 \mu \mathrm{g} / \mathrm{l})($ Dewanti, 2013).

Proses pengolahan emas yang menggunakan amalgamasi dengan merkuri dalam gelundung mudah ditemui di hampir seluruh titik rawan PESK di Indonesia, termasuk wilayah pemukiman di Desa Lebaksitu Banten. Hampir seluruh rumah tangga memiliki unit gelundung sendiri di halaman depan, halaman belakang, samping rumah atau dekat sawah untuk memproses biji emas. Gelundung-gelundung tersebut dioperasikan sepanjang hari tanpa menggunakan peralatan pengaman pribadi. Penelitian yang telah dilakukan di daerah ini diketahui kadar merkuri di air, tanah, dan ikan masing-masing sebesar 0,00392 ppm, 5,709 ppm, dan 0,5175 ppm menunjukkan kadar merkuri yang telah melebihi ambang batas dan mengindikasikan telah terjadi pencemaran lingkungan akibat merkuri (Agung dan Hutamadi, 2012). 
Merkuri memiliki sejumlah efek yang sangat merugikan pada manusia yaitu antara lain mengakibatkan terganggunya fungsi hati dan ginjal, mengganggu sistem enzim dan mekanisme sintetik (Darmono, 2001).Paparan merkuri dalam jangkan panjang mengakibatkan gangguan kesehatan pada manusia. Keracunan merkuri rawan terjadi pada masyarakat yang tinggal di sekitar penambangan. Umumnya bersifat kronik kecuali jika terpapar merkuri dalam kadar yang tinggi (Widowati, 2008). Efek toksik merkuri tergantung pada bentuk, jalan masuk, dan lamanya berkembang. Merkuri masuk ke dalam tubuh melalui pernafasan, pencernaan dan kulit. Merkuri yang masuk ke dalam tubuh terakumulasi pada bagian tubuh tertentu seperti ginjal, hati, kuku, jaringan lemak, dan rambut yang mengakibatkan keracunan sistem syaraf (Chamid, 2010). Toksisitas kronis akibat merkuri yang pernah terjadi adalah kasus keracunan di Pakistan Barat pada tahun 1963 dimana kadar Hg dalam darah di wilayah tambang emas rakyat di Pakistan menunjukkan kadar Hg rata-rata dalam darah untuk kelompok laki-laki paling tinggi $5,53 \mu \mathrm{g} / \mathrm{L}$ dan perempuan paling tinggi $5,28 \mu \mathrm{g} / \mathrm{L}$ sedangkan nilai batas maksimal Hg dalam darah menurut United State Environmental Protection Agency (US EPA, 2011) adalah 5,8 $\mu \mathrm{g} / \mathrm{L}$,. Selain itu juga terdapat beberapa kasus lainnya seperti kasus keracunan merkuri di Irak pada tahun 1961, kasus keracunan di Guatemala pada tahun 1966 dan kasus keracunan di Nigata Jepang pada tahun 1968 (Palar, 2004).

Pemeriksaan sampel darah adalah pilihan utama apabila pemaparan merkuri anorganik jangka pendek dengan konsentrasi tinggi karena konsentrasi merkuri dalam darah meningkat sangat cepat. Waktu paruh merkuri dalam darah adalah \pm 2 hari. Untuk pemaparan merkuri organik, pemeriksaan dilakukan dengan pengambilan sampel darah dan rambut. Pengukuran merkuri dalam darah biasanya digunakan untuk mengidentifikasi pemaparan metal merkuri (WHO,1990).

Pajanan metil merkuri dalam darah diambil beberapa hari setelah pajanan, karena sebagian besar bentukbentuk $\mathrm{Hg}$ dalam darah akan turun $50 \%$ setiap 3 hari jika pajanan dihentikan. Oleh karena itu kadar merkuri dalam darah merupakan informasi yang sangat bermanfaat untuk pajanan yang baru terjadi dibanding pajanan jangka panjang (Mahaffey, 2005). Menurut WHO (1991) dalam Warsono (2000), kadar merkuri maksimal dalam darah $500 \mu \mathrm{g} / \mathrm{l}$. Dalam kadar ini sudah dapat menimbulkan gejala parestesia dan disartria, sedangkan pada kadar 3000-4000 $\mu \mathrm{g} / 1$ akan berakibat kematian.

\section{METODE}

Penelitian dilakukan di PESK Desa Lebaksitu pada bulan Mei 2017. Metode penelitian cross sectional. Responden pada penelitian ini adalah masyarakat yang bertempat tinggal di sekitar PESK Lebaksitu, diperoleh 68 orang responden setelah ditentukan sesuai dengan kriteria inklusi dan eksklusi.

Data yang digunakan adalah data primer yang diperoleh dari hasil wawancara terhadap responden dan hasil uji laboratorium sampel darah. Pemeriksaan merkuri darah dengan menggunakan metode US EPA (1997) dianalisis dengan menggunakan Inductively Coupled Plasma Mass Spectrometry (ICP-MS) dalam waktu 14 hari (7). Variabel yang diteliti terdiri dari umur, jenis kelamin, pekerjaan dan lama tinggal. 


\section{HASIL}

Hasil pengukuran kadar merkuri dalam darah diperoleh sebanyak 77,9\% responden memiliki kadar merkuri darah melebihi $10 \mu \mathrm{g} / \mathrm{l}$ dengan rata-rata 26,94 $\mu / 1$ (Tabel 2). Hal ini menunjukkan responden sudah terpajan oleh merkuri dan akan menimbulkan dampak terhadap kesehatan.

Analisis hubungan terhadap karakteriktik responden dengan kadar merkuri dalam darah diperoleh dari karakteristik umur, jenis kelamin, pekerjaan dan lama tinggal (Tabel 1).

Tabel 1

DeskripsiResponden Menurut Umur, Jenis Kelamin, Jenis Pekerjaan, danLama Tinggal

\begin{tabular}{|c|c|c|c|}
\hline Variabel & & Jumlah (N) & Persentase $(\%)$ \\
\hline \multirow[t]{2}{*}{ Umur } & $\leq 40$ tahun & 43 & 63,3 \\
\hline & $>40$ tahun & 25 & 36,7 \\
\hline \multirow[t]{2}{*}{ Jenis Kelamin } & Perempuan & 53 & 77,9 \\
\hline & Laki-laki & 15 & 22,1 \\
\hline \multirow[t]{2}{*}{ Jenis Pekerjaan } & Bukan pengolah emas & 53 & 77,9 \\
\hline & Pengolah emas & 15 & 22,1 \\
\hline \multirow[t]{2}{*}{ Lama Tinggal } & $\leq 10$ tahun & 12 & 17,6 \\
\hline & $>10$ tahun & 56 & 82,4 \\
\hline
\end{tabular}

Berdasarkan tabel 1 deskripsi masyarakat desa Lebaksitu yang berumur kurang dari 40 tahun sebanyak 63,3\% yang merupakan usia produktif, berjenis kelamin perempuan sebanyak 77,9\%, jenis pekerjaan bukan pengolah emas sebanyak 77,9\% dan sudah tinggal di desa Lebaksitu lebih dari 10 tahun sebanyak 82,4\%.

Tabel 2 menunjukkan hasil pengukuran kadar merkuri darah responden kadar merkuri rata-rata adalah 26, $94 \mu \mathrm{g} / \mathrm{L}$ dengan kadar tertinggi 188,28 $\mu \mathrm{g} / \mathrm{L}$ serta dilakukan pengelompokkan kadar merkuri darah pada masyarakat berdasarkan nilai batas normal yang ditentukan, hasil penelitian diperoleh sebanyak 77,9\% masyarakat memiliki kadar merkuri darah di atas batas normal. Hal ini menunjukkan responden sudah terpajan oleh merkuri dan akan menimbulkan dampak terhadap kesehatan.

Tabel 2

Kadar Merkuri Darah ( $\mu \mathrm{g} / \mathrm{l})$ pada Masyarakat di Kawasan PESK Desa Lebaksitu Provinsi Banten Tahun 2017

\begin{tabular}{|c|c|c|c|c|}
\hline Variabel & Mean & SD & Min-mak & Jumlah (Persentase) \\
\hline Merkuri & 26,94 & 28,861 & $0,00-188,28$ & \\
\hline$\leq 10 \mu \mathrm{g} / \mathrm{l}$ & & & & $15(22,1)$ \\
\hline$>10 \mu \mathrm{g} / \mathrm{l}$ & & & & $53(77,9)$ \\
\hline
\end{tabular}


Tabel 3

Hubungan Karakteristik Responden terhadap Kadar Merkuri Darah ( $\mu$ g/L) pada Masyarakat di Kawasan PESK Desa Lebaksitu Provinsi Banten 2017

\begin{tabular}{|c|c|c|c|c|c|c|}
\hline \multirow{3}{*}{$\begin{array}{c}\text { Karakteristik } \\
\text { Responden }\end{array}$} & \multicolumn{4}{|c|}{ Kadar Merkuri Darah } & \multirow{3}{*}{$p . *$} & \multirow{3}{*}{$\begin{array}{c}\text { OR } \\
(\text { CI 95\%) }\end{array}$} \\
\hline & \multicolumn{2}{|c|}{$\leq 10 \mu \mathrm{g} / \mathrm{L}$} & \multicolumn{2}{|c|}{$>10 \mu \mathrm{g} / \mathrm{L}$} & & \\
\hline & $\mathbf{N}$ & $\%$ & $\mathbf{N}$ & $\%$ & & \\
\hline \multicolumn{7}{|l|}{ Umur } \\
\hline$\leq 40$ tahun & 10 & 23,3 & 33 & 76,7 & 1.000 & $1.212(0.362-4.059)$ \\
\hline$>40$ tahun & 5 & 20.0 & 20 & 80.0 & & \\
\hline \multicolumn{7}{|l|}{ Jenis Kelamin } \\
\hline Laki-laki & 1 & 6,7 & 14 & 93,3 & 0.161 & $5.026(0.604-41.813)$ \\
\hline Perempuan & 14 & 26,4 & 39 & 73,6 & & \\
\hline \multicolumn{7}{|l|}{ Pekerjaan } \\
\hline $\begin{array}{l}\text { Bukan pengolah } \\
\text { emas }\end{array}$ & 14 & 26.4 & 39 & 73,6 & 0.161 & $5.026(0,604-41.813)$ \\
\hline Pengolah emas & 1 & 6.7 & 14 & 93,3 & & \\
\hline \multicolumn{7}{|l|}{ Lama Tinggal } \\
\hline$\leq 10$ tahun & 0 & 0.0 & 12 & 100. & 0.050 & $1.366(1.166-1.600)$ \\
\hline$>10$ tahun & 15 & 26,8 & 41 & 73.2 & & \\
\hline
\end{tabular}

\section{PEMBAHASAN}

Pemeriksaan merkuri darah bertujuan untuk mengetahui dan mendeteksi apakah masyarakat telah terpajan oleh merkuri yang dapat menimbulkan efek toksik dalam tubuh. Hasil pemeriksaan merkuri menggunakan metode US EPA dengan alat ICP-MS dimana rata-rata merkuri dalam darah sebesar $26,94 \mu \mathrm{g} / \mathrm{l}$, dengan kadar minimum $0,00 \mu \mathrm{g} / \mathrm{l}$ dan maksimum $188,28 \mu \mathrm{g} / \mathrm{l}$. Kadar ini sudah melewati ketentuan nilai batas normal yang ditetapkan oleh WHO (2008) yang menyatakan bahwa kadar normal merkuri dalam darah yaitu>10 $\mu \mathrm{g} / \mathrm{l}$. Hal ini menunjukkan bahwa masyarakat Desa Lebaksitu sudah terpajan dengan merkuri dan akan mulai menimbulkan dampak kesehatan akibat dari pertambangan emas di wilayah tersebut.

Kadar merkuri dalam darah pada masyarakat di Desa Lebaksitu sudah melebihi kadar normal dikarenakan masyarakat di Desa Lebaksitu sudah lama terpajan merkuri mengingat PESK sudah ada lebih dari 20 tahun. Makin lama masyarakt terpajan merkuri makin tinggi pula kadar merkuri yang ada di dalam tubuhnya dan makin lama masyarakat tinggal di desa tersebut makin tinggi kadar merkuri, terutama pada masyarakat yang bekerja sebagai pengolah emas. Pekerja pengolah emas memiliki resiko lebih tinggi terpajan merkuri dibandingkan yang bukan pengolah emas karena mereka melakukan kontak langsung dengan merkuri.

Dalam penelitian Passostahun 2008 menunjukkan adanya kontaminasi merkuri akibat penambangan emas di sekitar Amazon, yaitu adanya toksisitas merkuri pada urin dan darah pekerja beserta tanda dan gejala keracunan merkuri, juga adanya kontaminasi merkuri di lingkungan baik di sumber air, sedimen maupun ikan di Amazon yang dikonsumsi oleh masyarakat sekitar.

\section{Umur dengan kadar merkuri dalam darah}

Tidak ditemukan hubungan yang bermakna antara umur dengan kadar merkuri dalam darah. Kemungkinan tersebut dipengaruhi oleh umur. Masyarakat yang mengalami keracunan merkuri maupun tidak, memiliki rata-rata umur yang masih tergolong usia produktif. Efek keracunan merkuri tergantung dari kepekaan individu, yakni anak dalam kandungan (prenatal), bayi, anak-anak, dan orang tua sehingga memungkinkan 
bahwa usia pekerja PESK di Desa Lebaksitu yang tergolong usia produktif, tidak memiliki pengaruh atau hubungan yang signifikan terhadap kejadian keracunan merkuri pada pekerja tersebut (Suma'mur, 1997).

\section{Jenis kelamin dengan kadar merkuri darah}

Tidak terdapat hubungan yang signifikan antara jenis kelamin dengan kadar merkuri dalam darah. Sebagian besar responden perempuan dan bekerja sebagai petani dan ibu rumah tangga dimana risiko terpajan merkuri lebih kecil dibandingkan responden laki-laki yang bekerja sebagai pengolah emas.

\section{Pekerjaan dengan kadar merkuri dalam darah}

Tidak ada hubungan yang signifikan antara pekerjaan dan kadar SGPT. Sebagian besar responden petani dan ibu rumah tangga, dimana resiko terpajan merkuri lebih kecil dibandingkan sebagai pengolah emas. Pengkategorian jenis pekerjaan berdasarkan pada resiko pajanan merkuri, dimana pekerja pengolah emas memiliki resiko untuk terpajan merkuri lebih besar dibandingkan dengan masyarakat biasa yang bukan merupakan pengolah emas. Pada responden yang bukan merupakan pengolah emas sebagian besar bekerja sebagai petani dan juga ibu rumah tangga.

Jenis pekerjaan merupakan salah satu faktor yang mempengaruhi kadar merkuri dalam tubuh (Wibisono, 2000). Pekerjaan yang berhubungan langsung atau kontak langsung dengan merkuri mempunyai peluang lebih besar terjadinya akumulasi merkuri dalam darah dibandingkan pekerjaan yang tidak kontak langsung dengan merkuri. Semakin lama bekerja di daerah terpapar maka akan semakin besar pula akumulasi kandungan keracunan merkuri pada tubuh (International Labour Office).

\section{Lama tinggal dengan kadar merkuri darah}

Terdapat hubungan yang signifikan antara lama tinggal dengan kadar merkuri dalam darah. Merkuri memliki sifat akumulatif sehingga lama tinggal dapat mempengaruhi kadar merkuri dalam tubuh. Semakin lama seseorang tinggal di daerah tercemar merkuri, semakin tinggi pula kandungan merkuri dalam tubuhnya (Tugaswati, 1997). Hasil penelitian Kementrian Lingkungan Hidup di Wonogiri, lama kerja berhubungan dengan keracunan merkuri (Kementerian Lingkungan Hidup, 2008). Meskipun memiliki perbedaan obyek yang diamati yaitu pekerja tambang dan masyarakat. Akan tetapi kedua variabel menunjukkan bahwa paparan merkuri yang lama akan meningkatkan kadar merkuri dan berdampak pada menurunnya gangguan kesehatan

\section{KESIMPULAN}

Sebanyak 77,9\% subyek penelitian memiliki kadar merkuri dalam darah di atas batas normal (10 $\mu \mathrm{g} / \mathrm{L})$ dan lama tinggal mempengaruhi kadar merkuri dalam darah pada masyarakat desa Lebaksitu. 


\section{DAFTAR PUSTAKA}

1. Agung LN dan Hutamadi R. Paparan Merkuri di Daerah Pertambangan Emas Rakyat Cisoka, Kabupaten Lebak, Provinsi Banten: Suatu Tinjauan Geologi Medis. Buletin Sumber Daya Geologi. 2012;7(3):133-46.

2. Bose-O'Reilly S et.al. Mercury Exposure and Children's Health. Current Problems in Pediatric and Adolescent Health Care. 2010;40(8):186-215.

3. Chamid, Chusharini dkk. 2010. Kajian Tingkat Konsentrasi Merkuri pada Rambut Masyarakat Kota Bandung. Bandung: Prosiding SNaPP Edisi Eksakta

4. Darmono. Logam dalam Sistem Biologi Makhluk Hidup. Jakarta: Universitas Indonesia; 2001.

5. Rianto S. Analisis Faktor-Faktor yang Berhubungan dengan Keracunan Merkuri pada Penambang Emas Tradisional di Desa Jendi Kecamatan Selogiri Kabupaten Wonogiri. Semarang: Universitas Diponegoro; 2010.

6. Dewanti NAY et.al. Hubungan Paparan Merkuri (Hg) dengan Kejadian Gangguan Fungsi Hati pada Pekerja Tambang Emas di Wonogiri. Jurnal Kesehatan Lingkungan Indonesia. 2013;12(1).

7. International Labour Office Geneva. Pencegahan Kecelakaan, Buku Pedoman. Jakarta: Gramedia.

8. Kementerian Lingkungan Hidup. Peraturan Menteri Negara Lingkungan Hidup No. 23 Tahun 2008 tentang Pedoman Teknis Pencegahan Pencemaran dan/atauKerusakan Lingkungan Hidup Akibat Pertambangan Emas Rakyat. Jakarta: KemenLH RI; 2008.

9. Mahaffey R, Kathryn. 2005. Mercury Exposure : Medical and Public Issues. Transactions of the American Clinical and Climatological Association Vol 116

10. Palar. 1994. Pencemaran dan Toksikologi Logam Berat. Jakarta : Rineka Cipta.

11. Passos and Mergler. 2008. Human mercury and adverse health effect in the Amazon. Rio de Jeneiro:Cad.Saudo Publica.; 24: Sup: 4-5503-5520

12. Ratnasari. (2014). Mencari Alternatif Solusi Pengelolaan Tambang Emas Rakyat. http://rmibogor. org/2014/04/mencari-alternatif-solusipengelolaan-tambang-emas-rakyat/

13. Setiabudi, B.T. (2005). Penyebaran Merkuri Akibat Usaha Pertambangan Emas Di Daerah Sangon, Kabupaten Kulon Progo, D.I Yogyakarta.

http://psdg.bgl.esdm.go.id/kolokium/Konservasi/61.\%20konservasi\%20-\%20Sangon, $\% 20$ Yogyakarta.pdf.

14. Sippl, K. (2015). Private and Civil Society Governors of Mercury Pollution from Artisanal and SmallScale Gold Mining: a Network Analytic Approach. The Extractive Industries and Society, 2(2015), 198-208.

15. Suma'mur. 1997. Higiene Perusahaan dan Kesehatan Kerja. Jakarta: PT Toko Gunung Agung

16. Tugaswati $\mathrm{T}$ et.al. Studi Pencemaran Merkuri dan Dampaknya terhadap Kesehatan Masyarakat di Daerah Mundu Kabupaten Indramayu. Balitbangkes. 1997;25(2).

17. UNEP. (2012). Reducing Mercury in Artisanal and Small-Scale Gold Mining (ASGM). http://www.unep.org/chemicalsandwaste/Mercury/GlobalMercuryPartnership/Artisana land 
SmallScaleGoldMining/tabid/3526/Default.as px US EPA. Exposure Factors Handbook: 2011 Edition. Washington: National Center for Environmental Assessment; 2011.

18. Veiga, M.M., Nunes, D., Klein, B., Shandro, J.A., Velasquez, P. C., and Sousa, R.N. (2009). Mill Leaching: a Viable Substitute for Mercury Amalgamation in the Artisanal Gold Mining Sector?. Journal of Cleaner Production, 17(2009) 1373-1381.

19. Warsono, S. 2002. Pengaruh Bahan Tambal Amalgam terhadap Kadar Merkuri pada Darah, Urin, Tinja, dan Rambut Kepala. Jurnal Kedokteran Gigi UI

20. WHO. Geneva. 1990. International Progamme on Chemical Safety. Biological

21. Widowati W, dkk. 2008. Efek toksik logam Pencegahan dan penanggulangan pencemaran. Yogyakarta :Penerbit Andi

22. WHO. Geneva. 1990. International Progamme on Chemical Safety. Biological 